\title{
THE QUALITY OF LIFE OF BREAST CANCER PATIENTS WITH CHEMOTHERAPY: A PHENOMENOLOGY STUDY
}

\author{
Fajar Firdaus $\mathbf{A}^{\mathbf{1}}$,Neni Nuraeni ${ }^{2}$, Hani Handayani ${ }^{3}$ \\ ${ }^{1,2,3}$ Faculty of Health, Nursing program, Universitas Muhammadiyah, Tasikmalaya, West Java, Indonesia \\ Correspondence: neni.nuraeni@umtas.ac.id
}

\begin{abstract}
Breast cancer patients experience physical and psychological changes. Psychic changes include sadness, worry, and fear related to the future and death. This psychological change would affect the quality of life. Data in the SMC Hospital Tasikmalaya District in 2017, the number of cancer cases reached 142, and $75 \%$ of them were stadium II and III with therapy namely chemotherapy. This study aimed to explore more deeply the quality of life of patients with cancer mammae who had chemotherapy. This qualitative research applied the phenomenology approach. Participants were selected by purposive sampling technique, 4 patients participated in this study. Data were analyzed by Collaizi methods. The results of the study found themes including the causes of physical limitations of breast cancer sufferers, sleep disorders of breast cancer patients, psychological problems of breast cancer sufferers and sexual relations of breast cancer sufferers. Nurses are advised to provide motivation and support for breast cancer patients by providing optimal nursing care to improve the quality of life of patients.
\end{abstract}

Keywords: breast cancer, hope, Quality of life

\section{INTRODUCTION}

Breast cancer (Carcinoma mammae) is a malignant neoplasm in the parenchyma (Carpenito, 2012). Breast cancer is a major health problem in women because it is identified with malignancy which results in death. Risk factors for breast cancer in women include increasing age, family history of breast cancer, high dose radiation to the chest, smoking, excessive weight, and alcoholics, (Soemitro, 2012 in Abdullah, 2013). Breast cancer had impacted significantly both physically and psychologically, including sadness, anxiety, and fear of the future and death. Changes in breast cancer patients would affect patients' quality of life.

This cancer is treatable using several treatments. Management of breast cancer includes surgery, chemotherapy, radiation, hormonal and immunological therapy. Chemotherapy is a cancer therapy method to provide substances or drugs that function to kill or inhibit cancer cells. According to (Prayoga, 2009), chemotherapy has two side effects namely physiological and psychological effects. The results of the Laksmiasanti's (2010) study found that the psychological impact on cancer patients was helplessness, anxiety, 
Fajar Firdaus : The Quality of Life of Breast Cancer Patients with Chemotherapy

shame, self-esteem, stress, depression, anger, inadequate coping. Cancer, and various problems faced by patients during illness and treatment stress for patients (Azizah, 2008).

Quality of life according to Preedy and Watson, (2010) decreases as a result of cancer disease. Satisfaction aspects measured are the physical function (functional status in daily life), psychological dysfunction (level of emotional distress), social function (interpersonal relationships in groups), treatment (anxiety or concern about disease and treatment programs), cognitive function (method for problem-solving).

The results of the qualitative research conducted by Pratiwi (2012) found that understanding aspects of quality of life would shape a person's positive attitude and also the subject's views on the things they experience. Suffering from cancer is understood as a process of personal maturation. There are personnel changes in cancer patients in a positive direction to survive. The Kiadaliri et al.'s (2012) study showed that breast cancer patients given chemotherapy using FAC had better Health-Related Quality of Life than patients given TAC (paclitaxel, doxorubicin, and cyclofosfamide). After 8 months of monitoring, there was a faster increase in patients given TAC than FAC. Demographic and socio-economic differences did not affect this study, but marital status, smoking and having children affected several HRQOL scales. Research Wulandari (2017) shows that the positive feelings felt by breast cancer patients include feelings of patience, optimism and a feeling of peace. The state of cognition of breast cancer sufferers was the ability to think logically, remember and concentrate were good. Components of self-esteem included self-confidence and hope, components of self-image included changes and satisfaction in body shape, and negative feelings of the patient, among others, anxious, sad and afraid.

Someone with cancer experiences changes in the way of life. Uncertainty about the remaining age and risk of death makes the patient feel his life is limited. Depressed attitude is very natural in cancer patients, but there are also patients who still look fresh and healthy 
Fajar Firdaus : The Quality of Life of Breast Cancer Patients with Chemotherapy

because they try to cover up their illness from people around them and behave like a healthy person. Patients who seek treatment programs to achieve healing, keep doing activities or jobs and have positive relationships with the people around them. These people usually have a positive quality of life.

\section{METHODS}

This qualitati ve study applied phenomenology approach. The aim in using this approach was to in deep exploration about the quality of life of cancer patients e specially patient with breast cancer and chemotherapy. The research setting was the SMC HospitalKabupaten, Tasikmalaya district. 4 women involved in this study, they were chosen using technique purposive sampling. The inclusion criteria incl ude living in Tasikmalaya, willinpayudarag to be a respon dent, and having good communication skill. the 4th participants had stadium II $(n=3)$ and stadium one person with breast cancer stadium III. Data were collected using the interview to respondent 2-3 times approximately 60 minutes. The interview was recorded using han dphone, after checking the memory and volume. Data were analyzed using Colaizzi methods

\section{RESULTS}

The results of the study describe based on the results of analysis and quotes from participants about an overview of the quality of life of breast cancer patients. According to data analysis, there are 5 themes:

1. Early symptoms of breast cancer

All participants said they felt a mass in the breast. The mass is located in the breast and underarm area. However, because the mass is not accompanied by pain, the participants did 
Fajar Firdaus : The Quality of Life of Breast Cancer Patients with Chemotherapy

not suspect as symptoms and signs of breast cancer. Following are the participants' expressions:

"Initially, there was a lump on this side (pointing to the armpit) but it didn't hurt" (P1)

"There is a mass in the armpit, it can be moved, and it doesn't hurt. So normal, at that times, I did not visit a doctor, then redness and pain”(P2)

"Initially I was not aware, I thought it wasn't cancer, there was a lump but it didn't hurt" (P3)

"Yes, sir, a few months ago there was a lump in the armpit but there was no pain" (P4)

2. Causes of physical limitations of breast cancer patients

Physical limitations experienced by participants due to severe pain. Following are the participants' expressions:

"Not like before, now everything hurts a lot and often. My activities while in pain were sitting in the bedroom, toilet, sometimes I went to the shop, very rarely I forced myself "(P1) "Oh God felt electrified, hurt a lot” (P2)

"It hurts, it hurts so much, it felt throbbing. I stayed at home because I felt sick and weak"(P3)

"Often pain, the pain was soo hard. When I have been treated, I felt well, then I forced my self to do activities such as shopping or attending a religion event "( $(\mathrm{P} 4)$ 


\section{Sleep disorders}

All participants experienced sleep disturbances due to the pain. P1 often wakes up during sleep due to feeling sore and supine sleeping position. Then in P2, P3, and P4 it was difficult to sleep, especially when they felt very strong pain. Here are the participants' expressions:

"Often wakes up, pain, but wanted to lie down (P1)

"Sometimes I couldn't sleep, because it was very pain sick, throbs at night (P2)

"Often couldn't sleep because of pain (P3)

"Sleeplessness, if you felt pain and woke up at night (P4)

\section{Psychological problems of breast cancer patients}

The psychological problems occurred when patients diagnosed with cancer, and the disease is difficult to cure. Following are the participants' expressions:

"... (participants cried) sad, sir, how is my life, it is inconceivable, like this, I just go through it, pray and try to meditate for a long time" (P1)

"How sad and confused, all illnesses from God, now I'm trying to accept it (P3)

"This may be the way of my life, when you asked me about my feeling, I wanted to cry, but no choices, this is a test from God (P4)

\section{Sexual intercourse of breast cancer patients}

Sexual relations with a husband are rarely done. Following are the participants' expressions:

"Yes, we do sex, but because of this illness becomes rare (P2)

"Yes, it's rare, we do it when I am not in pain or weak (P3)

"During illness is rarely, I forgot when the last time I having sex with my husband (P4) 
Fajar Firdaus : The Quality of Life of Breast Cancer Patients with Chemotherapy

\section{DISCUSSION}

1. Early symptoms of breast cancer

The initial symptoms felt by participants are a palpable mass, move, and not accompanied by pain. The mass is located in the breast and underarm area. This is in accordance with Mansjoer's theory (2012) that the initial symptoms of breast cancer are mass that is usually felt differently from the surrounding breast tissue, does not cause pain and usually has irregular margins. In the early stages, if the mass is pushed by the fingers, the lump can be moved easily under the skin. At an advanced stage, a lump is usually attached to the chest wall or the surrounding skin. In advanced cancer, it would take the form of a swollen lump or ulcers on the skin of the breast.

\section{Causes of physical limitations of breast cancer patients}

The results of the interviews found all participants felt pain in the breast. The pain affects the limited activity of the patient. All participants force themselves to carry out activities such as shopping near home and attend religious activities. Pratiwi's research (2012) suggests that symptoms of breast cancer can affect physical health, physical health can affect the ability of individuals to engage in activities. Activities carried out by individuals provide new experiences that are useful for development to the next stage. Physical health includes daily activities, dependence on drugs and medical assistance, energy and fatigue, mobility (easy to move), pain and discomfort, sleep and rest, and work capacity.

\section{Sleep disorders of breast cancer patients}

Special needs and sleep in participants could not be fulfilled, P1 often wakes up during sleep due to feeling sore and supine sleeping position. Then in P2, P3, and P4 it is difficult to sleep especially when feeling very pain. Physical health can affect an individual's ability to 
Fajar Firdaus : The Quality of Life of Breast Cancer Patients with Chemotherapy

carry out activities. Activities carried out by individuals would be useful experiences for life in the future. Physical health includes daily activities, dependence on drugs and medical assistance, energy and fatigue, mobility (a state of ease of movement), pain and discomfort, sleep and rest, work capacity.

Health conditions according to Cella et. al. (2003 in Pratiwi (2012) greatly influences a person's quality of life. Cella D (2013) says the quality of life is a good aspect of life that are influenced by health. In breast cancer, patients who have a good quality of life would have good physical health and positive mentality, for example, feeling healthy and able to do all of their own activities. Patients can accept and adapt to their illness even without medical treatment. Patients believe by instilling positive suggestions in their minds that they are healthy and well would make patients feel strong. Patients are confident about their physical condition.

\section{Psychological problems of breast cancer patients}

3 out of 4 participants initially felt very sad. This sadness was because this disease is difficult to cure and the treatment process takes times. Another concern experienced by participants was the fear that the disease would become more severe. Based on the results of the interview it can be found that all participants were afraid and worried about their illness. The fear is related to breast cancer that is getting bigger.

Psychological aspects are related to the individual's mental state. Mental circumstances lead to being able to adjust the demands of development in accordance with their abilities, both internal and external demands. Psychological aspects are also related to physical aspects, individuals can do an activity well when individuals are mentally healthy. 
Fajar Firdaus : The Quality of Life of Breast Cancer Patients with Chemotherapy

Patients can accept and adapt to the disease they suffer even without medical treatment. Patients believe by instilling suggestions in his mind that he is healthy and fine, it will make sufferers gain strength. Patients do not feel inferior to their physical condition.

5. Sexual intercourse with breast cancer patients

Sexual intercourse based on participants' experience, 3 out of 4 participants said they were still having sexual relations even though it was rarely done because they considered the health condition of the participants. Sexual relations is one aspect of social relations, the relationship between participants and their husbands. Reproductive health is an important component of health for both men and women but is more focused on women. The state of disease in women is more associated with reproductive function and ability, and social pressure in women. Women have special needs related to sexual and reproductive functions. Women have a reproductive system that is sensitive to damage and the risk of dysfunction or disease. Women are the subject of several diseases that attack their body functions due to the influence of men. The disease patterns of men and women are different because of differences in genetic, hormonal or lifestyle forms such as smoking habits, nutrition, and sexual practices. These things would support the increasing number of breast cancer patients (Baradero, 2007). Humans are social beings so that in their social relations they realize life and develop as whole human beings. Social relations include personal relationships, social support, and sexual activities.

\section{CONCLUSION}

The results of the study on the quality of life in breast cancer patient found 5 themes, including early symptoms of breast cancer, the cause of physical limitations of breast cancer patients, sleep disorders of breast cancer patients, psychological problems of breast cancer 
patients and sexual relations of breast cancer sufferers. It is recommended for nurses to provide motivation and support for breast cancer patients by providing optimal nursing care to improve the quality of life of patients.

\section{REFERENCES}

American Cancer Society. (2010). Breast Cancer Facts \& Figures. www.cancer.org/acs/groups/content/@nho/.3/f861009final90809pdf Diakses pada tanggal 18 Januari 2018.

Astana (2009).Bersahabat dengan kanker: Panduan mengelola dan mengobati kanker. Yogyakarta.

Barakat et. al. (2010) . Quality of Life of Adolesescent With Cancer: Family Risks and Resources. Health and Quality Outcomes. 8/1: 1-8

Cella D (2013). Faktor yang berpengaruh pada kualitas hidup pasein kanker. Anemia and Fatigue. Annals of Oncology. 25/6:1

Ferris (2010) . Approaches to Improving teh Quality of Life. Online. Dari http://library.nu/diakses 25 Januari 2018

Laksmiasanti (2010) Gambaran Fisik Dan Psikologis Klien Dengan Kanker Serviks Di Rumah Sakit Umum Daerah dr. Moewardi Surakarta

Larasati (2009) . Kualitas Hidup Pada Wanita yang Sudah Memasuki Masa Menopouse.

\section{Skripsi Universitas Gunadarma}

Pratiwi (2012). Kualitas hidup penderita kanker. Fakultas ilmu pendidikan. Universitas Negeri Semarang

Wahyuni (2015) Hubungan Antara Frekuensi Kemoterapi Dengan Kualitas Hidup Perempuan Dengan Kanker Payudara Yang Menjalani Kemoterapi Di Ruang Kemoterapi RSUD. A.M Parikesit Tenggarong 
Fajar Firdaus : The Quality of Life of Breast Cancer Patients with Chemotherapy

Wulandari (2017). Gambaran Kualitas Hidup Pada Penderita Kanker Payudara Di Rumah Sakit Umum Bahteramas Provinsi Sulawesi Tenggara Tahun 2017.VOL. 2.NO.6/ Mei 2017; ISSN 2502-731X. JimKesmas. Fakultas Kesehatan Masyarakat Universitas Halu Oleo. 